\title{
Effects of Lockdown due to the COVID-19 Pandemic on Air Quality at Latin America's Largest Open-pit Coal Mine
}

\author{
Heli A. Arregocés ${ }^{1,2^{*}}$, Roberto Rojano ${ }^{1}$, Gloria Restrepo ${ }^{2}$ \\ ${ }^{1}$ Grupo de Investigación GISA, Facultad de Ingeniería, Universidad de La Guajira, Riohacha, \\ Colombia \\ ${ }^{2}$ Grupo Procesos Fisicoquímicos Aplicados, Facultad de Ingeniería, Universidad de Antioquia \\ SIU/UdeA, Calle 70 No. 52-21, Medellín, Colombia
}

\section{ABSTRACT}

Particulate matter (PM) is the main pollutant produced by open-pit mining operations, and its emission into the atmosphere is strongly associated with adverse health effects in the surrounding communities. The objective of this study was to evaluate the effects of the COVID-19-related lockdown on the PM concentrations in the North, Central, and South Zones of Cerrejón, Colombia, the largest open-pit coal mine in Latin America. To compare the levels before and during the emergency shutdown, we analyzed both the ground-based daily $\mathrm{PM}_{10}$ and $\mathrm{PM}_{2.5}$ data and the satellite (Terra/Aqua MODIS)-based daily aerosol optical depth (AOD) values from March 6 through April 13, 2020. The average $\mathrm{PM}_{10}$ concentrations in the North and South Zones, in contrast to those observed at other global monitoring sites, increased by $13-38 \%$ and $4-7 \%$, respectively, although they decreased by $26-31 \%$ in the Central Zone, between the pre-lockdown and lockdown periods. Furthermore, during the latter, the daily $\mathrm{PM}_{2.5}$ levels in the South Zone rose by up to $43 \%$, and we found higher AOD values $(\geq 0.4)$ over the Central and South Zones as well as significant AOD-contributing loads upwind and downwind of the coal production pits. Finally, the increases in humidity and temperature $(\geq 3.5 \%$ and $\geq 0.3 \mathrm{~K}$, respectively), decrease in planetary boundary layer height $(\geq 0.11 \mathrm{~km})$, wind field variability, and rural biomass burning events shaped the spatial-temporal behavior of the PM in this region, and changes in meteorology and external sources nearly offset the reduction in emissions from mining activities. These results establish a baseline for developing future regulations and mitigation plans.

Received: December 15, 2020

Revised: April 13, 2021

Accepted: April 14, 2021

Keywords: Aerosol, Particulate matter, Meteorology, Lockdown

${ }^{*}$ Corresponding Author:

harregoces@uniguajira.edu.co

\section{Publisher:}

Taiwan Association for Aerosol Research

ISSN: $1680-8584$ print

ISSN: 2071-1409 online

Copyright: World Health Organization (WHO). This is an open access article distributed under the terms of the Creative Commons Attribution License (CC BY 4.0), which permits unrestricted use, distribution, and reproduction in any medium, provided the original author and source are cited.

\section{INTRODUCTION}

The new virus known as severe acute respiratory syndrome coronavirus 2 (SARS-CoV-2), which causes the coronavirus disease 2019 (COVID-19), is spreading rapidly around the world. Therefore, on March 11, 2020, the World Health Organization (WHO) declared COVID-19 a pandemic (WHO, 2020). A total of $103,912,620$ cases of COVID-19 had been confirmed worldwide since February 2,2021 , including 2,246,842 deaths in more than 220 countries. As of the same date, Colombia is among the top 11 countries in the world with the most reported cases of COVID-19, with 2,104,506 cases and 54,272 deaths (Worldometers, 2020). The first confirmed case of COVID-19 in Colombia was on March 6. The effects of the disease are not limited to an international health crisis but also a major impact on the economy and environment. The main measure to contain the pandemic was the implementation of lockdown to avoid the collapse of the health systems (Interior, 2020). As such, many industrial activities globally were reduced because of the measures implemented by governments (Madurai Elavarasan et al., 2020; Ju et al., 2021). Therefore, the scientific community has published thousands of articles in recent months on topics ranging from the origin and 
symptoms of the virus to environmental and socio-economic impacts caused by measures to control its spread (Huang et al., 2020; Nicola et al., 2020). Vitenu-Sackey and Barfi (2021) analyzed the effect of the pandemic on the economy of 170 countries during the first 10 months of 2020 and found that a single percentage point increase in COVID-19 cases could lead to a reduction of up to 0.049 in the Human Development Index, indicating the deterioration of poverty alleviation efforts. Okereke et al. (2021) highlighted that the effects of COVID-19 intensified the problem of provision in health systems in low- and middle-income countries, thereby further intensifying the global crisis of identifying non-communicable diseases.

Particulate matter (PM) is listed as the main indicator of air quality in urban and industrial areas due to its composition and sources of origin. Significant reductions of PM during the COVID19 pandemic have been found in cities (Chauhan and Singh, 2020; Dumka et al., 2020; Kumar et al., 2020; Singh et al., 2020) and industrial areas (Mandal and Pal, 2020; Ranjan et al., 2020; Selvam et al., 2020). Although traffic and PM emission activities have reduced, some studies report PM levels to increase (Arregocés et al., 2020; Broomandi et al., 2020). The increasing vehicle flow in urban and rural areas, industrial expansion, and dependence on the extraction of non-renewable resources expose Colombia to air pollution challenges (Casallas et al., 2020; Lopez-Restrepo et al., 2020). Studies to understand the environmental impact of the COVID-19 pandemic in Colombia have focused on analyzing urban and small industrial areas. MendezEspinosa et al. (2020) analyzed station records in urban areas. The results of their analysis reveal reductions of $\mathrm{PM}_{2.5}$ and $\mathrm{PM}_{10}$ by $40 \%$ and $44 \%$, respectively. Arregocés et al. (2020) considered variations in urban and industrial areas by limiting the data records of one monitoring station to be representative of a particular area. The authors found that there were reductions in $\mathrm{PM}_{2.5}$ of up to $86 \%$ in industrial zones during quarantine compared to days prior to quarantine. However, the impact of COVID-19 on air quality has not been rigorously analyzed in Colombia, considering mining activities and its directly impacted areas.

The main impact on the global mining sector has been a drastic reduction in demand as industrial production and construction have effectively stopped. This reduction affected mineral prices during March and April 2020 (Laing, 2020). In Colombia, coal mining is one of the main industries and contributes positively to the economic development of the country. Due to the COVID-19 pandemic, coal production in the country fell by $7 \%$ in the first quarter of 2020 , compared to the previous year, and by $48.8 \%$ in the second quarter (Villa, 2020). In the north of Colombia known as the "Caribbean region," is Cerrejón, the largest open-pit coal mine in Latin America. On March 27, 2020, Cerrejón placed $80 \%$ of its operational staff on leave to reduce the chances of infection among its workers, their families, and the general population (Cerrejón, 2020). Although the economic impact due to the reduction of activities in Cerrejón has been determined, the impact in terms of air quality in the area has not been quantified. Opencast coal mines are considered important sources of PM emissions (Huertas et al., 2012; Arregocés et al., 2018). The contaminants emitted can cause the deterioration of air quality in the vicinity of the emissions and hundreds of kilometers away (Chaulya, 2004).

This paper presents the changes in air quality in the largest open-pit coal mine in Latin America as a result of associated lockdown measures due to COVID-19. The analysis covers from March 6 to April 13, 2020. This study aims to first assess the levels of $\mathrm{PM}_{10}, \mathrm{PM}_{2.5}$, and aerosol optical depth (AOD) values in the zones that comprise the mining complex before and during the lockdown. Additionally, this research seeks to understand the impact of mining emissions and meteorological factors on the spatial variability of PM. The results of this research provide information on the national impact on air quality due to mining in northern Colombia.

\section{METHODS}

The Cerrejón mine is located in northern Colombia between latitudes $10.95-11.20^{\circ} \mathrm{N}$ and longitudes $72.50-72.80^{\circ} \mathrm{W}$. Cerrejón extends over $690 \mathrm{~km}^{2}$ and is divided into three sections, namely, North Zone, Central Zone, and South Zone. Geographically, the coal mine is located between the Perija mountain range in the east and the Santa Marta snow-capped mountain range in the west. The Perijá mountain range is an extension of the eastern branch of the Andes that ends in the Guajira desert to the north, reaching an altitude of $3630 \mathrm{~m}$ above sea level (ASL). On the 
other hand, the Sierra Nevada is one of the highest coastal ranges in the world, with an approximate altitude of $5700 \mathrm{~m}$ only $42 \mathrm{~km}$ from the Caribbean coast (Fig. 1).

\subsection{PM Data}

$\mathrm{PM}_{10}$ data were obtained from eight monitoring stations distributed over the three zones comprising the direct impact area of the open-pit coal mine. The stations that record $\mathrm{PM}_{10}$ levels use CFR equivalent method ( 40 CFR Part 58) given by the Environmental Protection Agency adopted by the Colombian regulations. In addition, an automatic $\mathrm{PM}_{2.5}$ monitoring station with a maximum operating volumetric flow of $5 \mathrm{~L} \mathrm{~min}^{-1}$ is located downwind in the South Zone. The equipment used in this station operates under the principle of aerosol optical depth. These data are readily available for download and are recorded in the air quality subsystem regulated by the Institute of Hydrology, Meteorology and Environmental Studies (IDEAM; http://www.ideam.gov.co/). The frequency for monitoring $\mathrm{PM}_{10}$ levels was $24 \pm 1 \mathrm{~h}$ every 3 days and for $\mathrm{PM}_{2.5}$ monitoring was 24 $\pm 1 \mathrm{~h}$ daily. Table 1 shows the coordinates, altitude, and characteristics of the stations. Daily concentrations were analyzed and compared between the pre-lockdown and lockdown.

\subsection{AOD Data}

Daily data during pre-lockdown and lockdown of the mid-visible optical depth of aerosol in the air column were extracted at $550 \mathrm{~nm}$ from the Moderate Resolution Imaging Spectroradiometer (MODIS) of the Terra and Aqua satellites. AOD denotes the column of integrated aerosols down to the surface of the atmosphere. The combined MODIS product (MCD19A2 Version 6) Level 2 aerosol over the study area was acquired from the NASA Level-1 and Atmosphere Archive \& Distribution System (LAADS) Distributed Active Archive Center (DAAC) (Lyapustin and Wang, 2018). The data used in this study were Terra/Aqua Collection 6 Dark Target algorithms of optical depth with $1 \mathrm{~km}$ resolution over the surface monitoring stations located in the coal mine.
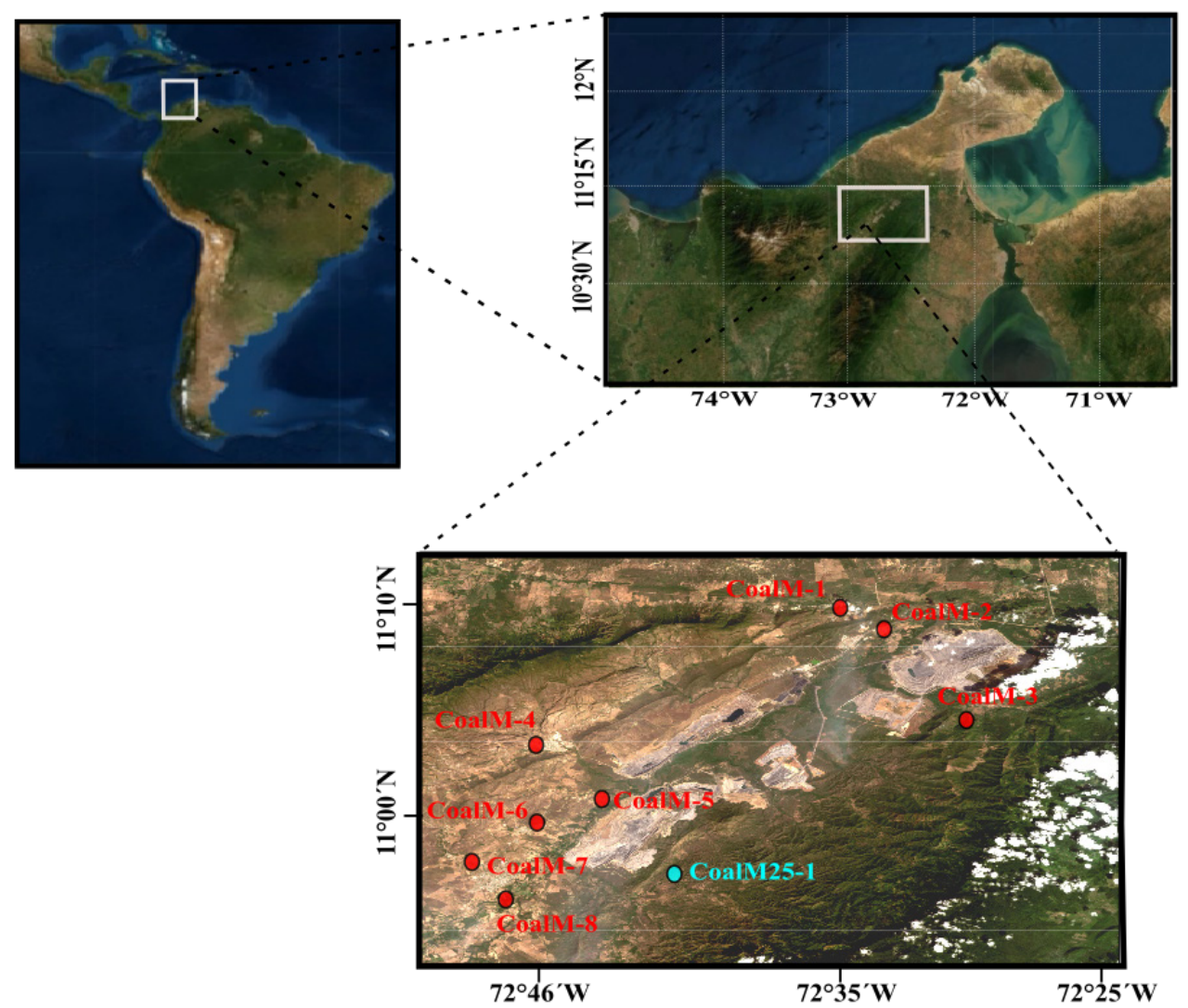

Fig. 1. Location of $\mathrm{PM}_{10}$ and $\mathrm{PM}_{2.5}$ monitoring stations at the largest open-pit coal mine in Latin America. The red labels represent the $\mathrm{PM}_{10}$ stations and the cyan label represents the $\mathrm{PM}_{2.5}$ monitoring station. 
Table 1. Description of the PM monitoring stations at Latin America's largest open-pit coal mine used to determine the impact before and during the lockdown.

\begin{tabular}{|c|c|c|c|c|c|}
\hline ID & Pollutants & $\begin{array}{l}\text { Mining } \\
\text { Zone }\end{array}$ & Coordinates & $\begin{array}{l}\text { Altitude } \\
\text { m ASL }\end{array}$ & Features \\
\hline CoalM-1 & $\mathrm{PM}_{10}$ & North & $\begin{array}{l}11^{\circ} 10^{\prime} 55.1^{\prime \prime} \mathrm{N} \\
72^{\circ} 36^{\prime} 29.3^{\prime \prime} \mathrm{W}\end{array}$ & 120 & $\begin{array}{l}\text { Located in a semi-urban area. The dominant emissions } \\
\text { are the activities of the North Zone of the mine and } \\
\text { unpaved access roads to administrative facilities. }\end{array}$ \\
\hline CoalM-2 & $\mathrm{PM}_{10}$ & North & $\begin{array}{l}11^{\circ} 09^{\prime} 27.1^{\prime \prime} \mathrm{N} \\
72^{\circ} 35^{\prime} 18.2^{\prime \prime} \mathrm{W}\end{array}$ & 95 & $\begin{array}{l}\text { Located in an urban area. The dominant emissions are } \\
\text { the activities of the North Zone of the mine. }\end{array}$ \\
\hline CoalM-3 & $\mathrm{PM}_{10}$ & North & $\begin{array}{l}11^{\circ} 05^{\prime} 57.6^{\prime \prime} \mathrm{N} \\
72^{\circ} 32^{\prime} 31.3^{\prime \prime} \mathrm{W}\end{array}$ & 155 & $\begin{array}{l}\text { Located in a rural windy area under the main coal mine } \\
\text { and back filling pit. }\end{array}$ \\
\hline CoalM-4 & $\mathrm{PM}_{10}$ & Central & $\begin{array}{l}11^{\circ} 03^{\prime} 50.3^{\prime \prime} \mathrm{N} \\
72^{\circ} 45^{\prime} 58.6^{\prime \prime} \mathrm{W}\end{array}$ & 201 & $\begin{array}{l}\text { Located in an urban area. The dominant emissions are } \\
\text { the activities of the Central Zone of the mine. }\end{array}$ \\
\hline CoalM-5 & $\mathrm{PM}_{10}$ & Central & $\begin{array}{l}11^{\circ} 01^{\prime} 26.5^{\prime \prime} \mathrm{N} \\
72^{\circ} 44^{\prime} 15.2^{\prime \prime} \mathrm{W}\end{array}$ & 130 & $\begin{array}{l}\text { Located downwind approximately } 3.6 \mathrm{~km} \text { from the } \\
\text { mining sources located in the Central Zone. }\end{array}$ \\
\hline CoalM-6 & $\mathrm{PM}_{10}$ & South & $\begin{array}{l}10^{\circ} 59^{\prime} 43.5^{\prime \prime} \mathrm{N} \\
72^{\circ} 46^{\prime} 26.4^{\prime \prime} \mathrm{W}\end{array}$ & 155 & $\begin{array}{l}\text { Located approximately } 3 \mathrm{~km} \text { from the mining sources in } \\
\text { an urban area. }\end{array}$ \\
\hline CoalM-7 & $\mathrm{PM}_{10}$ & South & $\begin{array}{l}10^{\circ} 57^{\prime} 40.1^{\prime \prime} \mathrm{N} \\
72^{\circ} 46^{\prime} 41.5^{\prime \prime} \mathrm{W}\end{array}$ & 141 & $\begin{array}{l}\text { Located downwind of mining sources and urban } \\
\text { emission sources. }\end{array}$ \\
\hline CoalM-8 & $\mathrm{PM}_{10}$ & South & $\begin{array}{l}10^{\circ} 56^{\prime} 29.1^{\prime \prime} \mathrm{N} \\
72^{\circ} 48^{\prime} 09.7^{\prime \prime} \mathrm{W}\end{array}$ & 143 & $\begin{array}{l}\text { Located in a semi-urban area influenced by paved road } \\
\text { traffic. }\end{array}$ \\
\hline CoalM25-1 & $\mathrm{PM}_{2.5}$ & South & $\begin{array}{l}10^{\circ} 57^{\prime} 9.95^{\prime \prime} \mathrm{N} \\
72^{\circ} 42^{\prime} 6.89^{\prime \prime} \mathrm{W}\end{array}$ & 197 & $\begin{array}{l}\text { Located } 2 \mathrm{~km} \text { from the backfill area and the main pit of } \\
\text { the South Zone. Located in a rural area and upwind } \\
\text { from indigenous communities. }\end{array}$ \\
\hline
\end{tabular}

A descriptive analysis of daily AOD values, represented in line graphs, was performed for the prelockdown and lockdown. The space-time pattern of the mean AOD level is described in two diagrams: (1) 15 days prior to lockdown (March 6-25, 2020) and (2) during the first 15 days of lockdown (March 26-April 13, 2020). In addition, the Terra MODIS satellite daily thermal anomaly dataset (MOD14A1 Version 6) was analyzed to identify forest fires and biomass burning as a source of aerosol input to the atmosphere during pre-lockdown and lockdown. The data obtained provided daily fire mask compounds with a resolution of $1 \mathrm{~km}$ derived from MODIS radiances of 4 and $11 \mu \mathrm{m}$. MODIS C6 active fire location data (Giglio and Justice, 2016). Each active fire detection represents the center of a $1 \mathrm{~km}$ marked pixel containing one or more fires.

\subsection{Meteorology}

To determine the effects of meteorology on PM levels, simulations were performed with the Weather Research and Forecasting (WRF) numerical model. The WRF is a numerical Eulerian model that allows for the realization of downscaling of thousands of kilometers within a few meters. In this study, we used the WRF Model Version 4 to estimate the temperature at $2 \mathrm{~m}$ above ground (T2), wind speed at $10 \mathrm{~m}$ above ground (WS10), relative humidity (RH), and height of the planetary boundary layer (PBLH). Three computational domains were nested with horizontal grid resolutions of 18,6 , and $2 \mathrm{~km}$ east-west and north-south. The fine resolution of the $2 \mathrm{~km}$ domains allowed the analysis of meteorological variables in the areas of the mining complex where the PM monitoring stations are located. The initial and lateral conditions in the model simulations were obtained from the European Centre for Medium-Range Weather Forecasts (ECMWF) ERA5 dataset at grid resolutions of $0.25^{\circ} \times 0.25^{\circ}$. The simulations started at 01:00 UTC on February 20, 2020, and ended at 00:00 UTC on April 14, 2020. The spin-up was $720 \mathrm{~h}$. For the configurations of the microphysics scheme, the Thompson scheme, New Tiedtke scheme for cumulus parameterization, and RRTMG scheme for long- and shortwave radiation were used. In addition, for the surface layer scheme, the revised parameterization of the MM5 model was selected. For the planetary boundary layer scheme, the Yonsei University scheme was used. Estimates of hourly values of $\mathrm{RH}, \mathrm{T} 2$, and WS10 using the WRF model were validated with data from the observations of the only meteorological station in the study area $\left(11.13^{\circ} \mathrm{N}, 72.62^{\circ} \mathrm{W}\right)($ Table S1). The meteorological 
variables for each of the zones of the Cerrejón mine were estimated by averaging the estimates given by the model at each point where the monitoring stations are located during pre-lockdown and lockdown. In addition, daily estimates of the PBLH and mean wind speed within the PBL were used to estimate the ventilation coefficient (VC) as a complement to atmospheric dispersion analysis (Chan et al., 2012).

\section{RESULTS AND DISCUSSION}

\subsection{PM Concentrations and AOD Values}

Fig. 2 shows daily $\mathrm{PM}_{10}$ concentrations at eight monitoring stations distributed over the three zones of the coal mine, daily $\mathrm{PM}_{2.5}$ concentrations at one monitoring station located in the South Zone, and average estimates of daily AOD values for the entire study zone. The time of the strict quarantine is highlighted in light pink color. The days between March 6 and March 25, called prelockdown, were used as references for the analysis. The strict lockdown was extended until April 13. Therefore, 19 days of social isolation and restrictions given by government authorities are counted.

In the North Zone, average $\mathrm{PM}_{10}$ concentrations recorded at the stations during lockdown were higher compared to pre-lockdown. A comparison of the mean concentration values from the two periods shows an increase in $\mathrm{PM}_{10}$ levels of $13.16 \%, 16.27 \%$, and $37.58 \%$ at CoalM-1, CoalM-2,
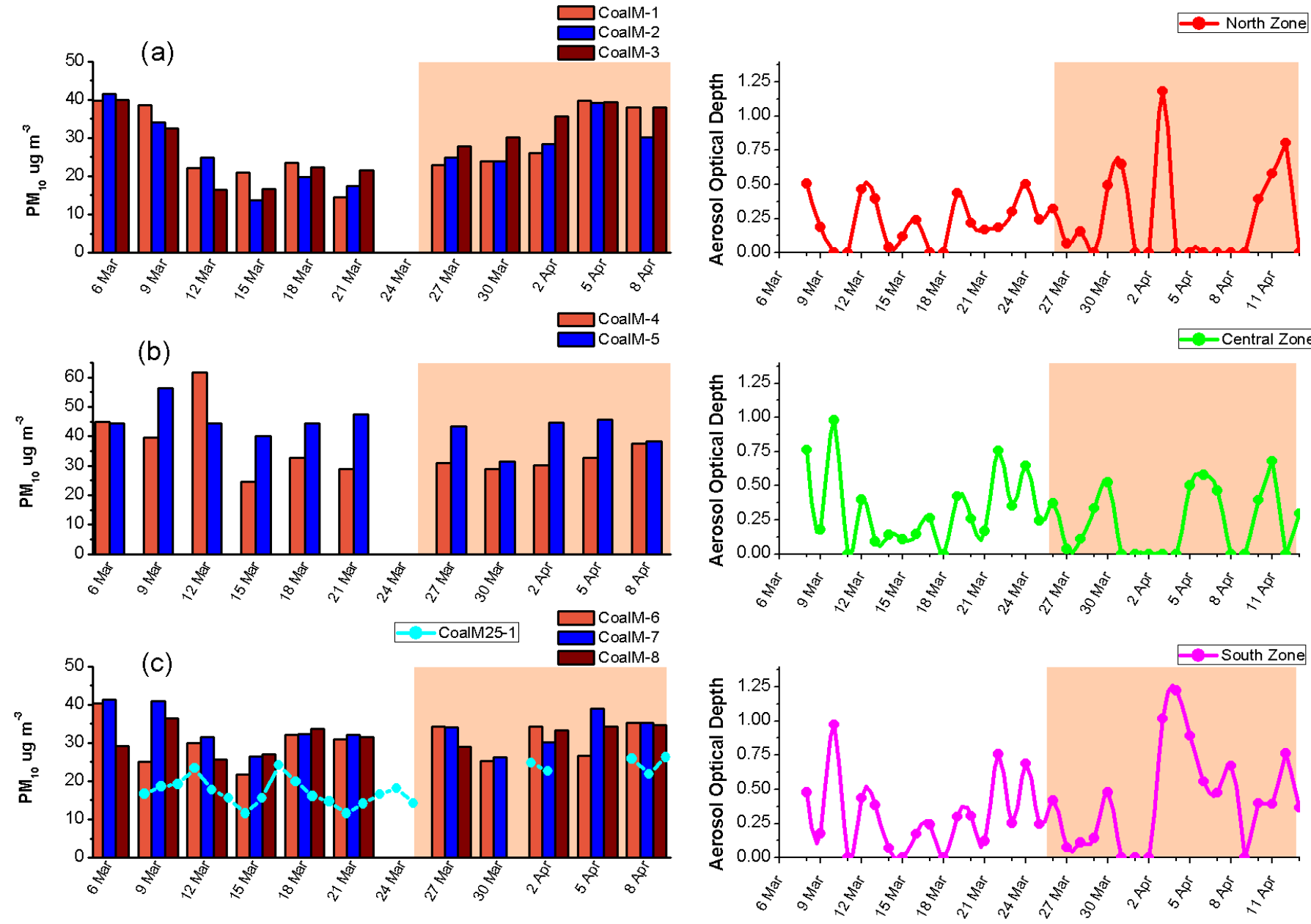

Fig. 2. $P M$ concentrations during pre-lockdown and lockdown due to COVID-19 at the largest open-pit coal mine in Latin America: (a) records from three $\mathrm{PM}_{10}$ monitoring stations and daily AOD estimates in the North Zone; (b) records from two PM 10 monitoring stations and daily AOD estimates in the Central Zone; and (c) records from three $\mathrm{PM}_{10}$ monitoring stations, one $\mathrm{PM}_{2.5}$ station, and daily AOD estimates in the South Zone. The lockdown began on March 25. 
and CoalM-3 stations, respectively. Meanwhile, significant reductions in $\mathrm{PM}_{10}$ levels were recorded at CoalM-4 (3-25\%) and CoalM-5 (1-32\%) stations located in the Central Zone of the coal mine. The largest reductions were achieved on Day 6 (CoalM-4 $=9.72 \mu \mathrm{g} \mathrm{m}^{-3}$ and CoalM-5 $=14.70 \mu \mathrm{g} \mathrm{m}^{-3}$ ) of the lockdown. In the South Zone, $\mathrm{PM}_{10}$ concentrations averaged $1.21 \mu \mathrm{g} \mathrm{m}^{-3}$ at CoalM-7 and increased by $1.11 \mu \mathrm{g} \mathrm{m}^{-3}$ at CoalM-6 and $2.19 \mu \mathrm{g} \mathrm{m}^{-3}$ at CoalM-8 during lockdown, compared to the pre-lockdown averages. Furthermore, the $\mathrm{PM}_{2.5}$ recording station showed an increase in daily concentrations in lockdown of $23.82 \pm 1.94 \mu \mathrm{g} \mathrm{m}^{-3}$. Studies have shown that the North Zone of the mine generates the highest number of emissions reaching the atmosphere. However, topography and wind direction transport PM to the South Zone. PM monitoring stations located in the South Zone have recorded the highest levels of concentrations downwind of the extraction pits (Arregocés et al., 2018; Rojano et al., 2018). April 4 was the most polluted day during the quarantine. On this day, six of the eight $\mathrm{PM}_{10}$ monitoring stations recorded the highest concentrations ranging between $26.7-45.8 \mathrm{\mu g} \mathrm{m}^{-3}$, which represented an increase of 5-33\% in the average concentrations during the quarantine period. On April 6 , AOD estimates were $\simeq 0.57$ in the Central and South Zones. A fairly significant dust plume from the mine pits was observed on April 5 and 7. A preliminary analysis revealed a $15 \%$ reduction in PBLH and an increase in $\mathrm{RH}$ compared to the average value observed during the period.

The daily analysis of the pre-lockdown and lockdown AOD averages, shown in Fig. 2, reveals that the temporal variations of the AOD values exhibit a behavior similar to the average $\mathrm{PM}_{10}$ concentrations in the study areas. Decreasing trends of average AOD values in the Central Zone and increases in the North and South Zones of the open-pit coal mine during lockdown are also shown. There was an average increase in AOD in the North Zone of 0.02 and South Zone of 0.11 in the lockdown, peaking on April 3 (1.18) and April 4 (1.22), respectively. There are more days where AOD values are zero (North Zone $=10$ days and South Zone $=4$ days) during lockdown. Conversely, in the Central Zone, there are 8 days when the satellite does not detect AOD values; the reductions of the daily average values are estimated to be $31 \%$.

The spatial variation of daily AOD values in the pre-lockdown and lockdown periods in the study area are shown in Fig. 3. In the pre-lockdown, the spatial distribution of high AOD ( 0.4) is located over the southern part of the domain area. Moreover, a significant load of AOD ( 0.25) is shown downwind the coal mine production pits. Throughout lockdown, the spatial load of AOD increases in the atmosphere, especially in the south-central zone $(\geq 0.5)$. The AOD values increase (0.3-0.5) upwind of the coal extraction pits compared to the AOD values during pre-lockdown. In both periods, the figures show the AOD loads in the northwestern sector of the domain $(\geq 0.25)$. The spatial variability of AOD is not associated with precipitation because the region's weather station and numerical simulations did not record precipitation during these days of analysis. A study in coal mining regions of various mining basins in India demonstrated a positive AOD anomaly (between 11-40\%) due to ongoing mining operations, while negative AOD anomalies

\section{Pre-lockdown}

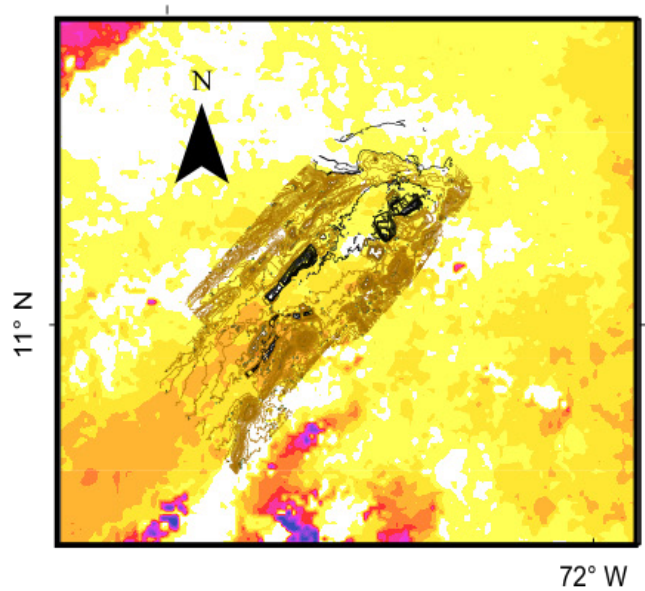

Lockdown

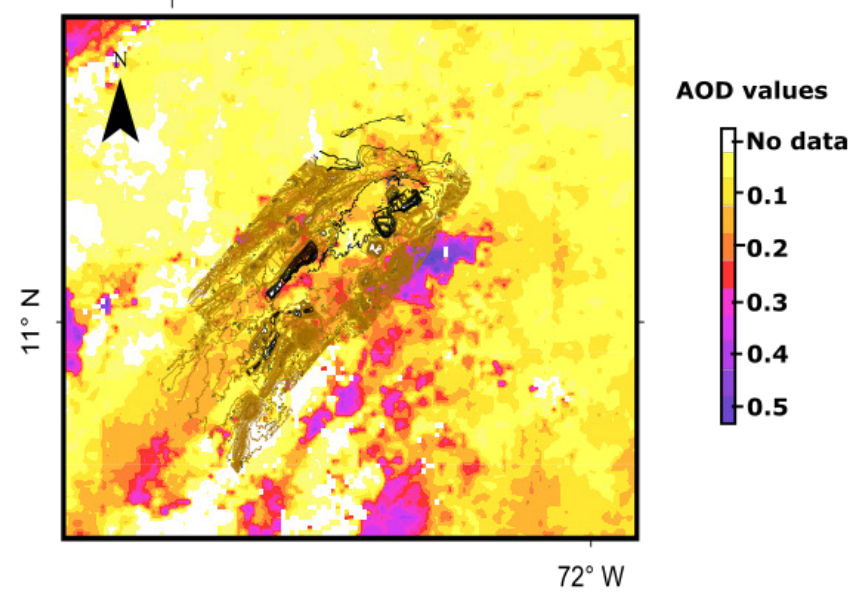

Fig. 3. Spatial variation of AOD in the pre-lockdown and lockdown in Latin America's largest open-pit coal mine. 
were observed in other parts of the country during the lockdown; the spatiotemporal variation of mining pit locations and the quantity of coal extracted directly influenced the AOD levels (Ranjan et al., 2020).

When comparing the daily values of $\mathrm{PM}_{10}$ concentrations and $A O D$ values, no significant linear behavior was observed $\left(R^{2} \geq 0.5\right)$. All $P M_{10}$ surface stations recorded their maximum values during the pre-lockdown period with the exception of the CoalM-1 station, which recorded its maximum value $\left(39.8 \mu \mathrm{g} \mathrm{m}^{-3}\right)$ in early April. On the contrary, the AOD values in North and South Zones reached their maximum during the lockdown, implying a higher vertical distribution of PM during this period. The linear regression function of daily $\mathrm{PM}_{10}$ concentrations $(y)$ and the observed daily AOD values $(x)$ were different in the three study zones: $y=67 x+12\left(R^{2}=0.34\right.$, in the North Zone), $y=16 x+$ $35\left(R^{2}=0.11\right.$, in the Central Zone), and $y=10 x+28\left(R^{2}=0.31\right.$, in the South Zone). In the observed data, $R^{2}$ ranged from 0.11 to 0.34 , the slopes of the functions ranged from 10 to 6 , and the intercept ranged from 12 to 28 in the three study zones. According to the results, the AOD values could explain up to $34 \%$ of the spatiotemporal variability of surface $\mathrm{PM}_{10}$. The declining performance of these statistical models can be attributed to factors such as scarcity of PM 10 concentration data to fit the model, changes in $\mathrm{PM}_{10}$ vertical profiles, and optical properties of the pollutants on the surface. The trends of $\mathrm{PM}_{10}$ and $\mathrm{AOD}$ averages during the pre-lockdown and lockdown periods were similar. Higher values in the North and South Zones were observed during the quarantine for both datasets. On the other hand, due to the availability of $\mathrm{PM}_{2.5}$ data and WRF output estimates, we determined a regression model to explain the variations of PM using AOD data.

Although AOD can be used as a metric to estimate overall air pollution levels, it is typically used as a proxy of $\mathrm{PM}_{2.5}$ concentration. The multiple linear regression function of $\mathrm{PM}_{2.5}$ and groundobserved AOD was PM $=-0.27 \mathrm{AOD}-0.02 \mathrm{PBLH}+0.06 \mathrm{RH}+1.9 \mathrm{~T} 2-0.2 \mathrm{WS}\left(\mathrm{R}^{2}=0.60\right.$, in the South Zone). The results indicate that the statistical model for predicting $\mathrm{PM}_{2.5}$ concentrations is significant. The function shows that when AOD values are greater than 0.3 , estimates are performed for the entire column detecting the surface $\mathrm{PM}_{2.5}$ concentrations. Furthermore, the relationship between PBLH-WS and $\mathrm{PM}_{2.5}$ concentrations is inverse. Subsection 3.2 discusses the meteorological effects on $\mathrm{PM}$ concentrations and $\mathrm{AOD}$ values during the study periods.

\subsection{Effects of Meteorology}

Simulations for wind vectors averaged over the periods show the significant influence of wind direction on the spatial variation of AOD (Fig. S1). The predominant trend of wind direction over the coal mine pre-lockdown is northeast. During the night throughout the quarantine period, average wind speeds decreased, and the predominant wind direction was from the east in the North Zone and the Central Zone. Meanwhile, the predominant wind direction in the South Zone was from the north, with higher wind speeds observed during the hours of solar radiation. These behaviors favor the receptivity in the coal mine of PM from regional sources, such as marine aerosols and the burning of biomass. When analyzing the thermal anomalies, a strong association is shown between higher values of AOD over the Central and South Zones of the mining area during both periods and the occurrence of forest fires and biomass burning in rural areas of Colombia and Venezuela (Fig. S2). Considering the decrease in mining PM emissions, PM levels are influenced by PBL dynamics and wind strength. Therefore, VC values were determined during the pre-lockdown and lockdown periods. The Central Zone reached the highest average daily VC values during the pre-lockdown $\left(3480 \pm 532 \mathrm{~m}^{2} \mathrm{~s}^{-1}\right)$ and lockdown $\left(3149 \pm 952 \mathrm{~m}^{2} \mathrm{~s}^{-1}\right)$, whereas the North Zone recorded the lowest coefficient during the pre-lockdown $\left(2556 \pm 580 \mathrm{~m}^{2} \mathrm{~s}^{-1}\right)$, and the South Zone recorded the lowest average value during the lockdown $\left(2478 \pm 991 \mathrm{~m}^{2} \mathrm{~s}^{-1}\right)$. A decreasing trend is generally observed after April 1 for VC values during quarantine in the Central Zone (14-50\%) and South Zone (10-81\%) when compared to the days prior to the lockdown (Fig. S3). Reduced VC and increased humidity values influenced hydroscopic growth and secondary aerosol formation, leading to increased AOD values and PM levels at the surface (Eck et al., 2020). These conditions may generate a positive aerosol-PBLH feedback that should be studied further to deepen the understanding of air quality in open-pit mining in the region. Increased surface aerosols and PM can substantially reduce sensible heat fluxes by decreasing PBL depth and weakening winds, creating favorable conditions for increased aerosol concentrations (Li et al., 2017; Liu et al., 2017). 
Considering all variations, it is shown that the highest aerosol loads in the area are due to forest fires in Colombia and Venezuela, transfer of marine aerosols, and contributions from mining emissions. The higher AOD values $(\geq 0.4)$ observed during the lockdown in the Central and South Zones of the mine are related to the convergence of wind in these zones, especially during nighttime. The load of sea salt aerosol (which is hydrophilic) from the ocean to the mining zone is significant if zero precipitation and wind fields during lockdown are considered. This difference has impacted the aerosol load on the mining areas. Although the company reports a reduction in activities during lockdown, aerosol load from mining activities is shown near the pits and downwind.

During the lockdown, other near-surface weather variables play an important role in the spatial-temporal behavior of PM levels. Daily values of PBLH, T2, RH, and WS10 before and during lockdown are shown in Fig. 4. RH has average values of $72.67 \pm 3.51 \%, 76.86 \pm 4.60 \%$, and 72.46 $\pm 5.93 \%$ in the North, Central, and South Zones of the coal mine. Local conditions plus humidity compared to the pre-lockdown period were present in all zones. For example, in the Central Zone, the average daily moisture values were $2.56 \%$ higher with daily values ranging from $68.56 \%$ to $83.13 \%$. Meanwhile, average T2 values were higher in the North (by $1.70 \mathrm{~K}$ ), Central (by $1.45 \mathrm{~K}$ ), and South (by $1.61 \mathrm{~K}$ ) Zones during lockdown than during pre-lockdown. The Central Zone presented the lowest average T2 value among the three zones at $300.02 \mathrm{~K}$ during lockdown. On the other hand, the higher averages of daily WS10 during lockdown were higher for the North Zone $\left(0.24 \mathrm{~m} \mathrm{~s}^{-1}\right)$. Meanwhile, in the Central $\left(0.1 \mathrm{~m} \mathrm{~s}^{-1}\right)$ and South $\left(0.30 \mathrm{~m} \mathrm{~s}^{-1}\right)$ Zones, the average WS10 values were reduced compared to the pre-lockdown period. However, the highest average value during the isolation period is estimated in the Central Zone $\left(4.80 \pm 0.67 \mathrm{~m} \mathrm{~s}^{-1}\right)$ compared
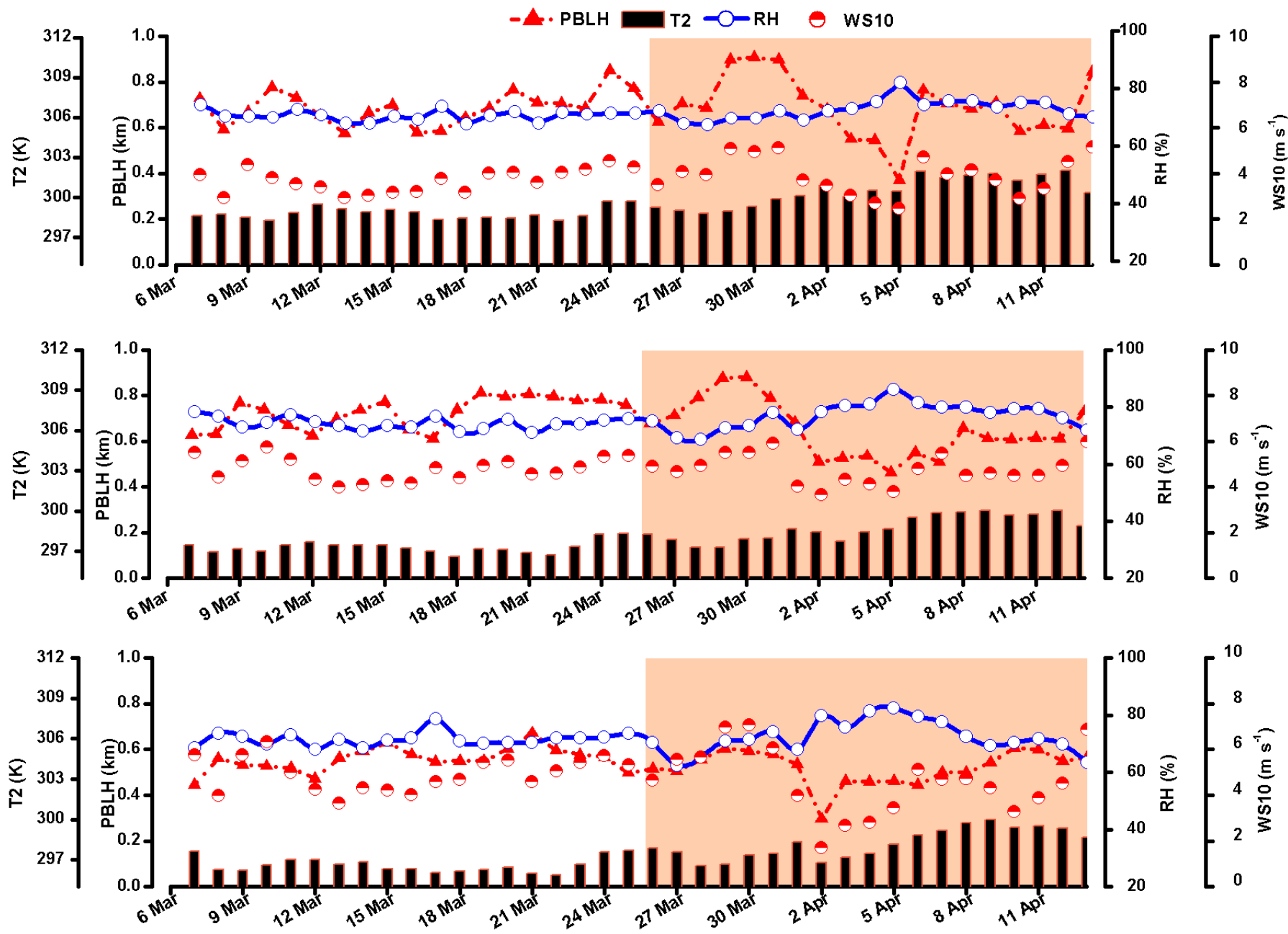

Fig. 4. Daily values of PBLH, T2, RH, and WS10 at one of the world's largest open-pit mines before and during lockdown. 
to the other two zones. When comparing the average PBLH values before and during the lockdown, reductions were estimated in the Central $(\simeq 0.077 \mathrm{~km})$ and South $(\simeq 0.040 \mathrm{~km})$ Zones, while there was an increase in the North Zone $(\simeq 0.002 \mathrm{~km})$. A lower PBLH in the confined zone plus particles that are concentrated near the surface lead to higher $\mathrm{PM}_{2.5}$ values. During the first 7 days of the quarantine period, a significant increase in PBLH daily average values was observed in the North Zone (up to $0.08 \mathrm{~km}$ ) and the Central Zone (up to $0.018 \mathrm{~km}$ ) compared to the prelockdown PBLH daily average values. Throughout these days, increases in the average daily surface temperature of $0.81 \mathrm{~K}$ and $0.75 \mathrm{~K}$ were estimated for the North and Central Zones, respectively, with average daily humidity values below $73 \%$. These conditions result in higher sensible heat flux and lower latent heat flux, leading to deeper convection, higher buoyancy, and increased PBLH (Zhang et al., 2013). After April 1, the PBLH showed decreasing trends, reaching reductions of up to $0.135 \mathrm{~km}$ and $0.156 \mathrm{~km}$ in the North and Central Zones of the mine complex, respectively. Average increases in $\mathrm{RH}$ (of up to 6\%) tend to favor hygroscopic growth of aerosols and to reduce the amount of solar radiation reaching the ground (Zou et al., 2017). The reduction in sensible heat drives a diurnal evolution of the PBL (Li et al., 2017). During the PBLH reduction days, wind speed reductions were observed for the North Zone $\left(0.55 \mathrm{~m} \mathrm{~s}^{-1}\right)$, Central Zone $\left(0.26 \mathrm{~m} \mathrm{~s}^{-1}\right)$, and South Zone $\left(1.01 \mathrm{~m} \mathrm{~s}^{-1}\right)$. These meteorological conditions favor increased PM concentrations at the surface. Studies have found that low PBLH values are typically characterized by reduced wind speeds (Zhang et al., 2014; Liu et al., 2017; de Arruda Moreira et al., 2018).

We used the conditional probability function (CPF) method, described in Uria-Tellaetxe and Carslaw (2014) for identifying the source contributions to $\mathrm{PM}_{2.5}$ concentrations. CPF was coupled with the back-trajectory cluster analysis, as established by Bennett et al. (2013), to provide more information on the contributions of sources located at long distances. CPF revealed three significant sources. In the northwest direction, mining activities are observed, as shown in Fig. S4(a). The largest contributions were recorded in the northwest direction from nearby sources, with the recorded $\mathrm{PM}_{2.5}$ concentrations ranging between 7 and $18 \mu \mathrm{g} \mathrm{m}^{-3}$ (40\% of the contributions were from this source). Two potential major sources of $\mathrm{PM}_{2.5}$ in the east-northeast (ENE) and south directions contributed to the $\mathrm{PM}_{2.5}$ concentrations, thereby reaching a daily average of $18-30 \mu \mathrm{g} \mathrm{m}^{-3}$ as shown in Fig. S4(b). The 24-h back-trajectory analysis showed that contributions from marine aerosols predominated in the ENE direction, accounting for approximately $20 \%$ of the $\mathrm{PM}_{10}$ concentrations (18-30 $\mathrm{g} \mathrm{m}^{-3}$ ) during the pre-lockdown period (Fig. S4(c)). During this period, in the south direction, contributions from biomass burning from nearby areas were estimated to be up to $60 \%$. 52 active biomass burning fires were identified within a $15 \mathrm{~km}$ radius during the pre-lockdown period. The identification of this source explains the thermal anomalies recorded by the Terra MODIS satellite (Fig. 3). The source identified in the northeast direction and shown in Fig. S4(d) corresponds to a combination of marine aerosols and biomass burning at approximately $60 \mathrm{~km}$ away from the source. Contributions ranged from $20-30 \%$ at the concentrations of $18-$ $30 \mu \mathrm{g} \mathrm{m}^{-3}$ during the lockdown. Thermal anomalies revealed an approximate reduction of $32 \%$ in active fires compared to the days prior to the start of the quarantine.

Based on the comparisons, an increase in $\mathrm{PM}_{10}$ concentrations was observed at stations located in the North (13-38\%) and South (4-7\%) Zones during lockdown, while a reduction was observed at stations located in the Central Zone (26-31\%). The $\mathrm{PM}_{2.5}$ station located in the South Zone showed an increase of up to $43 \%$ compared to pre-lockdown. The temporal variation in the mining zones of the $A O D$ values is similar to the $\mathrm{PM}_{10}$ concentrations in both periods. The average values in the Central Zone decreased (down to 31\%) and increased in the North (up to 10\%) and South (up to 35\%) Zones during lockdown. The spatial variation of daily AOD values during lockdown increased in the atmosphere, especially in the Central and South Zones $(\geq 0.5)$. Furthermore, there was a significant increase (0.3-0.5) in the vicinity of the extraction pits during lockdown. Before and during the lockdown, there was evidence of AOD loads in the northwestern sector of the domain $(\geq 0.25)$ from the coastal zone of the region. The data obtained provided by the daily fire mask compounds derived from MODIS radiances show the presence of active fires in rural areas of the countries of Colombia and Venezuela. Sanap (2021) estimated global and regional variations in aerosol loading imposed by the lockdown. Their results show that, in northern Colombia where our study area is located, forest fire emissions contributed significantly to the high aerosol and associated negative aerosol radiative forcing anomalies during the April lockdown. When combined with regional meteorology, they contribute to variations in PM values over coal 
mine areas. During lockdown, the variations in wind direction were northwest-east. During daytime, the predominant direction was northeast-east, carrying biomass burning aerosols in rural areas. During nighttime, the predominant wind direction was northwest-northeast, carrying aerosols from the mining area by rural fires presented to the west of the department and particles from the ocean. Rainfall was zero during the period of analysis. Increased aerosol presence can suppress precipitation and the formation of open cell structures, leading to significant changes in PBL evolution (Jiang et al., 2002; Ackerman et al., 2004). The spatial variability of AOD is not associated with precipitation because the region's weather station and numerical simulations did not record precipitation during these days of analysis. During lockdown, local environmental conditions were wetter (up to $3.5 \%$ ) and warmer (up to $0.3 \mathrm{~K}$ ) compared to pre-lockdown. The high temperatures and relative humidity conditions aid the gas-to-particle process, producing more secondary sulfate particles and inducing hygroscopic growth of the particles in the atmosphere (Achtert et al., 2009). Some aerosol species like $\mathrm{H}_{2} \mathrm{SO}_{4}$, some organics and sea salt, thus being able to take up water and grow or shrink smoothly as the RH increases (Kamra et al., 1997). Creating conditions that facilitate hygroscopic growth of particles in the atmosphere. It is estimated that $\mathrm{RH}$ values between $60 \%$ and $90 \%$ induce the hygroscopic growth of aerosols as they increase the gradient potential at a rate of $0.2 \mathrm{~V} \mathrm{~m}^{-1}$ for each unit increase in $\mathrm{RH}$ (Silva et al., 2015). Wu et al. (2021) found that relative humidity and temperature increase the levels of air pollutants. The trend showed reductions in PBLH (up to $0.11 \mathrm{~km}$ ) on lockdown days over coal mine areas. The decrease in PBLH benefited from increased surface PM concentrations by providing unfavorable diffusion conditions (Luan et al., 2018). Su et al. (2020) found that contamination episodes in northern China, during isolation due to the COVID-19 pandemic, coincided with an abnormally low PBLH, which had been reduced by $45 \%$ compared to the PBLH during the same period in the previous four years; this caused high levels of aerosol at the lower surface of the atmosphere. The weather was generally unfavorable in the decrease in PM concentrations, increasing surface concentrations. The reduction in emissions from PM-mining activities was almost compensated for by changes in meteorology during the lockdown.

Air mass turbulence during the day ascends to $2 \mathrm{~km}$ at average speeds of $0.6 \mathrm{~m} \mathrm{~s}^{-1}$; the highest velocities occur in the South Zone $\left(1.21 \mathrm{~m} \mathrm{~s}^{-1}\right)$. The model generally estimates air descent for the study zones (Fig. S5). Due to changes in the ground surface in this zone, the absorption of energy in the form of heat plays an important role in the surface temperature and consequently influences atmospheric processes on a short time scale. It is estimated that emissions are discharged into the atmosphere at a higher velocity in the South Zone than in the other zones. Variations in the vertical velocity increase the dispersion of aerosols and vertical velocities are estimated to affect aerosol-cloud formation relationships (Lu et al., 2012). As vertical velocity increases, droplet concentration increases, and relative cloud dispersion decreases. To estimate the effect of vertical velocity on the behavior of aerosol levels in the studied mining region, high-frequency measurements of vertical motions and measurements of microphysical and radiative quantities in the turbulent cloud area are needed (Peng et al., 2005). Interpretations of the results of the present investigation should consider that, at the $\mathrm{PM}_{10}$ and $\mathrm{PM}_{2.5}$ monitoring stations, direct emissions from mining activities and regional emission contributions to aerosol variability were being quantified during the COVID-19 pandemic. Additionally, WRF Model simulations allow for a determination of the meteorological effects on aerosol loading on daily time scales. However, how cloud microphysics, shortwave and longwave radiation, and PBL parameterization may affect the variability of aerosol levels is not studied. This study provides an opportunity to further examine the relationships of surface-level concentrations of PM and sensitivity in the parameterization of meteorological models widely used in research.

\section{CONCLUSIONS}

The COVID-19-related lockdown significantly increased the average $\mathrm{PM}_{10}$ concentrations at several monitoring stations in Cerrejón, Latin America's largest coal mine, with daily values rising by $13-38 \%$ and $4-7 \%$ in the North and South Zones, respectively, which was mainly associated with rural biomass burning, regional wind fields, and the decreased PBLH. In the coal mine's Central Zone, however, the daily concentrations decreased by $26-31 \%$, which was associated with 
the wind speed (averaging $4.80 \pm 0.67 \mathrm{~m} \mathrm{~s}^{-1}$ at $10 \mathrm{~m}$ above the ground) and wind direction Additionally, the $\mathrm{PM}_{2.5}$ levels measured at the South Zone station grew by up to $43 \%$ between the pre-lockdown and lockdown periods owing to the weather conditions and active fires in this area.

Furthermore, the daily AOD values decreased in the Central Zone (by $\leq 31 \%$ ) but increased in the North (by $\leq 10 \%$ ) and South (by $\leq 35 \%$ ) Zones during the lockdown. The AOD's spatialtemporal variability in this period was related to the wetter (by $\leq 3.5 \%$ ) and warmer (by $\leq 0.3 \mathrm{~K}$ ) conditions, which, by promoting gas-to-particle conversion, produced more secondary sulfate and induced the hygroscopic growth of atmospheric particles. Regional transport from the ocean and from active fires also contributed to the aerosol loads, and overall, changes in meteorology and other sources nearly offset the reduction in mining-related emissions during the lockdown.

Thus, our results highlight the necessity of rigorously examining PM reduction measures in northern Colombia that are based on restricting emissions from open-pit coal mines. Both the source contributions and the meteorological factors in this region must be investigated.

\section{ACKNOWLEDGMENTS}

The author would like to thank MinCiencias Colombia (Biannual Plan-Excellence Scholarship Program), the University of La Guajira and University of Antioquia.

\section{SUPPLEMENTARY MATERIAL}

Supplementary material for this article can be found in the online version at https://doi. org/10.4209/aaqr.200664

\section{REFERENCES}

Achtert, P., Birmili, W., Nowak, A., Wehner, B., Wiedensohler, A., Takegawa, N., Kondo, Y., Miyazaki, Y., Hu, M., Zhu, T. (2009). Hygroscopic growth of tropospheric particle number size distributions over the North China Plain. J. Geophys. Res. 114, D00G07. https://doi.org/10.1029/2008JD010921

Ackerman, A.S., Kirkpatrick, M.P., Stevens, D.E., Toon, O.B. (2004). The impact of humidity above stratiform clouds on indirect aerosol climate forcing. Nature 432, 1014-1017. https://doi.org/ 10.1038/nature03174

Arregocés, H.A., Rojano, R., Angulo, L., Restrepo, G. (2018). Intake fraction of $\mathrm{PM}_{10}$ from coal mine emissions in the north of Colombia. J. Environ. Public Health 2018, 8532463. https://doi.org/10.1155/2018/8532463

Arregocés, H.A., Rojano, R., Restrepo, G. (2020). Impact of lockdown on particulate matter concentrations in Colombia during the COVID-19 pandemic. Sci. Total Environ. 764, 142874. https://doi.org/10.1016/j.scitotenv.2020.142874

Bennett, N.D., Croke, B.F.W., Guariso, G., Guillaume, J.H.A., Hamilton, S.H., Jakeman, A.J., MarsiliLibelli, S., Newham, L.T.H., Norton, J.P., Perrin, C., others (2013). Characterising performance of environmental models. Environ. Modell. Software 40, 1-20. https://doi.org/10.1016/j.envs oft.2012.09.011

Broomandi, P., Karaca, F., Nikfal, A., Jahanbakhshi, A., Tamjidi, M., Kim, J.R. (2020). Impact of COVID-19 event on the air quality in Iran. Aerosol Air Qual. Res. 20, 1793-1804. https://doi.org/10.4209/aaqr.2020.05.0205

Casallas, A., Celis, N., Ferro, C., López Barrera, E., Peña, C., Corredor, J., Ballen Segura, M. (2020). Validation of $\mathrm{PM}_{10}$ and $\mathrm{PM}_{2.5}$ early alert in Bogotá, Colombia, through the modeling software WRF-CHEM. Environ. Sci. Pollut. Res. 27, 35930-35940. https://doi.org/10.1007/s11356-01906997-9

Cerrejon (2020). CERREJON is acting to avoid contagion from COVID-19. https://www.cerre jon.com/index.php/cerrejon-is-acting-to-avoid-contagion-from-covid-19/?lang=en (accessed 1 November 2020).

Chan, L., Deng, Q.H., Liu, W.W., Huang, B.L., Shi, L.Z. (2012). Characteristics of ventilation 
coefficient and its impact on urban air pollution. J. Cent. South Univ. 19, 615-622. https://doi.org/10.1007/s11771-012-1047-9

Chauhan, A., Singh, R.P. (2020). Decline in $\mathrm{PM}_{2.5}$ concentrations over major cities around the world associated with COVID-19. Environ. Res. 187, 109634. https://doi.org/10.1016/j.envres. 2020.109634

Chaulya, S.K. (2004). Assessment and management of air quality for an opencast coal mining area. J. Environ. Manage. 70, 1-14. https://doi.org/10.1016/j.jenvman.2003.09.018

de Arruda Moreira, G., Guerrero-Rascado, J.L., Bravo-Aranda, J.A., Benavent-Oltra, J.A., OrtizAmezcua, P., Róman, R., Bedoya-Velásquez, A.E., Landulfo, E., Alados-Arboledas, L. (2018). Study of the planetary boundary layer by microwave radiometer, elastic lidar and Doppler lidar estimations in Southern Iberian Peninsula. Atmos. Res. 213, 185-195. https://doi.org/10.1016/ j.atmosres.2018.06.007

Dumka, U.C., Kaskaoutis, D.G., Verma, S., Ningombam, S.S., Kumar, S., Ghosh, S. (2020). Silver linings in the dark clouds of COVID-19: Improvement of air quality over India and Delhi metropolitan area from measurements and WRF-CHIMERE model simulations. Atmos. Pollut. Res. 12, 225-242. https://doi.org/10.1016/j.apr.2020.11.005

Eck, T.F., Holben, B.N., Kim, J., Beyersdorf, A.J., Choi, M., Lee, S., Koo, J.H., Giles, D.M., Schafer, J.S., Sinyuk, A., Peterson, D.A., Reid, J.S., Arola, A., Slutsker, I., Smirnov, A., Sorokin, M., Kraft, J., Crawford, J.H., Anderson, B.E., Thornhill, K.L., et al. (2020). Influence of cloud, fog, and high relative humidity during pollution transport events in South Korea: Aerosol properties and $\mathrm{PM}_{2.5}$ variability. Atmos. Environ. 232, 117530. https://doi.org/10.1016/j.atmosenv.2020.117 530

Giglio, L., Justice, C. (2015). MOD14A1 MODIS/Terra Thermal Anomalies/Fire Daily L3 Global 1km SIN Grid V006. NASA EOSDIS Land Processes DAAC. https://doi.org/10.5067/MODIS/MOD14A1.006

Huang, C., Wang, Y., Li, X., Ren, L., Zhao, J., Hu, Y., Zhang, L., Fan, G., Xu, J., Gu, X., Cheng, Z., Yu, T., Xia, J., Wei, Y., Wu, W., Xie, X., Yin, W., Li, H., Liu, M., Xiao, Y., et al. (2020). Clinical features of patients infected with 2019 novel coronavirus in Wuhan, China. Lancet 395, 497-506. https://doi.org/10.1016/S0140-6736(20)30183-5

Huertas, J.I., Huertas, M.E., Izquierdo, S., González, E.D. (2012). Air quality impact assessment of multiple open pit coal mines in northern Colombia. J. Environ. Manage. 93, 121-129. https://doi.org/10.1016/j.jenvman.2011.08.007

Interior, M. del (2020). Decreto 457 de 2020. Minist. del Inter. Colomb.

Jiang, H. (2002). Simulations of aerosol-cloud-dynamical feedbacks resulting from entrainment of aerosol into the marine boundary layer during the Atlantic Stratocumulus Transition Experiment. J. Geophys. Res. 107, 4813. https://doi.org/10.1029/2001JD001502

Ju, M.J., Oh, J., Choi, Y.H. (2021). Changes in air pollution levels after COVID-19 outbreak in Korea. Sci. Total Environ. 750, 141521. https://doi.org/10.1016/j.scitotenv.2020.141521

Kamra, A.K., Deshpande, C.G., Gopalakrishnan, V. (1997). Effect of relative humidity on the electrical conductivity of marine air. Q. J. R. Meteorol. Soc. 123, 1295-1305. https://doi.org/1 0.1002/qj.49712354108

Kumar, P., Hama, S., Omidvarborna, H., Sharma, A., Sahani, J., Abhijith, K.V., Debele, S.E., ZavalaReyes, J.C., Barwise, Y., Tiwari, A. (2020). Temporary reduction in fine particulate matter due to 'anthropogenic emissions switch-off' during COVID-19 lockdown in Indian cities. Sustainable Cities Soc. 62, 102382. https://doi.org/10.1016/j.scs.2020.102382

Laing, T. (2020). The economic impact of the Coronavirus 2019 (Covid-2019): Implications for the mining industry. Extr. Ind. Soc. 7, 580-582. https://doi.org/10.1016/j.exis.2020.04.003

Li, Z., Guo, J., Ding, A., Liao, H., Liu, J., Sun, Y., Wang, T., Xue, H., Zhang, H., Zhu, B. (2017). Aerosol and boundary-layer interactions and impact on air quality. Natl. Sci. Rev. 4, 810-833. https://doi.org/10.1093/nsr/nwx117

Liu, T., Gong, S., He, J., Yu, M., Wang, Q., Li, H., Liu, W., Zhang, J., Li, L., Wang, X., Li, S., Lu, Y., Du, H., Wang, Y., Zhou, C., Liu, H., Zhao, Q. (2017). Attributions of meteorological and emission factors to the 2015 winter severe haze pollution episodes in China's Jing-Jin-Ji area. Atmos. Chem. Phys. 17, 2971-2980. https://doi.org/10.5194/acp-17-2971-2017

Lopez-Restrepo, S., Yarce, A., Pinel, N., Quintero, O.L., Segers, A., Heemink, A.W. (2020). Forecasting $\mathrm{PM}_{10}$ and $\mathrm{PM}_{2.5}$ in the Aburrá Valley (Medellín, Colombia) via EnKF based data assimilation. Atmos. Environ. 232, 117507. https://doi.org/10.1016/j.atmosenv.2020.117507 
Lu, C., Liu, Y., Niu, S., Vogelmann, A.M. (2012). Observed impacts of vertical velocity on cloud microphysics and implications for aerosol indirect effects. Geophys. Res. Lett. 39, L21808. https://doi.org/10.1029/2012GL053599

Luan, T., Guo, X., Guo, L., Zhang, T. (2018). Quantifying the relationship between $\mathrm{PM}_{2.5}$ concentration, visibility and planetary boundary layer height for long-lasting haze and fog-haze mixed events in Beijing. Atmos. Chem. Phys. 18, 203-225. https://doi.org/10.5194/acp-18203-2018

Lyapustin, A., Wang, Y. (2018). MCD19A2 MODIS/Terra+Aqua Land Aerosol Optical Depth Daily L2G Global 1 km SIN Grid V006. NASA EOSDIS Land Processes DAAC. https://doi.org/10.5067/ MODIS/MCD19A2.006

Madurai Elavarasan, R., Shafiullah, G.M., Raju, K., Mudgal, V., Arif, M.T., Jamal, T., Subramanian, S., Sriraja Balaguru, V.S., Reddy, K.S., Subramaniam, U. (2020). COVID-19: Impact analysis and recommendations for power sector operation. Appl. Energy 279, 115739. https://doi.org/10.1 016/j.apenergy.2020.115739

Mandal, I., Pal, S. (2020). COVID-19 pandemic persuaded lockdown effects on environment over stone quarrying and crushing areas. Sci. Total Environ. 732, 139281. https://doi.org/10.1016/ j.scitotenv.2020.139281

Mendez-Espinosa, J.F., Rojas, N.Y., Vargas, J., Pachón, J.E., Belalcazar, L.C., Ramírez, O. (2020). Air quality variations in Northern South America during the COVID-19 lockdown. Sci. Total Environ. 749, 141621. https://doi.org/10.1016/j.scitotenv.2020.141621

Nicola, M., Alsafi, Z., Sohrabi, C., Kerwan, A., Al-Jabir, A., Iosifidis, C., Agha, M., Agha, R. (2020). The socio-economic implications of the coronavirus pandemic (COVID-19): A review. Int. J. Surg. 78, 185-193. https://doi.org/10.1016/j.ijsu.2020.04.018

Okereke, M., Ukor, N.A., Adebisi, Y.A., Ogunkola, I.O., Favour lyagbaye, E., Adiela Owhor, G., Lucero-Prisno III, D.E. (2021). Impact of COVID-19 on access to healthcare in low-and middleincome countries: Current evidence and future recommendations. Int. J. Health Plann. Manage. 36, 13-17. https://doi.org/10.1002/hpm.3067

Peng, Y., Lohmann, U., Leaitch, W.R. (2005). Importance of vertical velocity variations in the cloud droplet nucleation process of marine stratus clouds. J. Geophys. Res. 110, D21213. https://doi.org/10.1029/2004JD004922

Ranjan, A.K., Patra, A.K., Gorai, A.K. (2020). Effect of lockdown due to SARS COVID-19 on aerosol optical depth (AOD) over urban and mining regions in India. Sci. Total Environ. 745, 141024. https://doi.org/10.1016/j.scitotenv.2020.141024

Rojano, R.E., Arregoces, H.A., Angulo, L.C., Restrepo, G.M. (2018). Analysis and Origin of TSP and $\mathrm{PM}_{10}$ Concentrations in Open-pit Coal Mining using Polar Plots. Inf. Tecnol. 29, 131-142. https://doi.org/10.4067/S0718-07642018000600131

Sanap, S.D. (2021). Global and regional variations in aerosol loading during COVID-19 imposed lockdown. Atmos. Environ. 246, 118132. https://doi.org/10.1016/j.atmosenv.2020.118132

Selvam, S., Muthukumar, P., Venkatramanan, S., Roy, P.D., Manikanda Bharath, K., Jesuraja, K. (2020). SARS-CoV-2 pandemic lockdown: Effects on air quality in the industrialized Gujarat state of India. Sci. Total Environ. 737, 140391. https://doi.org/10.1016/j.scitotenv.2020.140391

Silva, H.G., Conceição, R., Wright, M.D., Matthews, J.C., Pereira, S.N., Shallcross, D.E. (2015). Aerosol hygroscopic growth and the dependence of atmospheric electric field measurements with relative humidity. J. Aerosol Sci. 85, 42-51. https://doi.org/10.1016/j.jaerosci.2015.03.003

Singh, V., Singh, S., Biswal, A., Kesarkar, A.P., Mor, S., Ravindra, K. (2020). Diurnal and temporal changes in air pollution during COVID-19 strict lockdown over different regions of India. Environ. Pollut. 266, 115368. https://doi.org/10.1016/j.envpol.2020.115368

Su, T., Li, Z., Zheng, Y., Luan, Q., Guo, J. (2020). Abnormally shallow boundary layer associated with severe air pollution during the COVID-19 lockdown in China. Geophys. Res. Lett. 47, e2020GL090041. https://doi.org/10.1029/2020GL090041

Uria-Tellaetxe, I., Carslaw, D.C. (2014). Conditional bivariate probability function for source identification. Environ. Modell. Software 59, 1-9. https://doi.org/10.1016/j.envsoft.2014.05.002

Villa, S. (2020). Colombia's coal industry pins hopes of salvation on China. https://dialog ochino.net/en/extractive-industries/38033-colombia-coal-industry-pins-hopes-of-salvation-o n-china/ (accessed 2 November 2020).

Vitenu-Sackey, P.A., Barfi, R. (2021). The impact of Covid-19 pandemic on the global economy: 
Emphasis on poverty alleviation and economic growth. Econ. Finance Lett. 8, 32-43. https://doi.org/10.18488/journal.29.2021.81.32.43

World Health Organization (WHO) (2020). WHO Director-General's opening remarks at the media briefing on COVID-19 - 11 March 2020. https://www.who.int/dg/speeches/detail/who-directorgeneral-s-opening-remarks-at-the-media-briefing-on-covid-19---11-march-2020 (accessed 6 July 2020).

Worldometers (2020). Coronavirus statistics. https://www.worldometers.info/coronavirus/

Wu, Q., Tang, Y., Wang, L., Wang, S., Han, D., Ouyang, D., Jiang, Y., Xu, P., Xue, Z., Hu, J. (2021). Impact of emission reductions and meteorology changes on atmospheric mercury concentrations during the COVID-19 lockdown. Sci. Total Environ. 59, 1-9. https://doi.org/10.1 016/j.scitotenv.2020.142323

Zhang, R.H., Li, Q., Zhang, R.N. (2014). Meteorological conditions for the persistent severe fog and haze event over eastern China in January 2013. Sci. China Earth Sci. 57, 26-35. https://doi.org/10.1007/s11430-013-4774-3

Zhang, Y., Seidel, D.J., Zhang, S. (2013). Trends in planetary boundary layer height over Europe. J. Clim. 26, 10071-10076. https://doi.org/10.1175/JCLI-D-13-00108.1

Zou, J., Sun, J., Ding, A., Wang, M., Guo, W., Fu, C. (2017). Observation-based estimation of aerosol-induced reduction of planetary boundary layer height. Adv. Atmos. Sci. 34, 1057-1068. https://doi.org/10.1007/s00376-016-6259-8 